\title{
Las cofradías castellanas en la Edad Media. Pasado, presente y futuro de la producción historiográfica*
}

\author{
Castilian confraternities in the Middle Ages. Past, \\ present and future in historical scholarship
}

Antonio Martín-Viveros Tajuelo**

\begin{abstract}
RESUMEN
El análisis historiográfico de los estudios sobre el asociacionismo y las cofradías en

la Castilla medieval pone de manifiesto que este tema ha experimentado en los últimos quince años el gran impulso que no había conseguido desarrollar en las décadas de la renovación de los estudios sobre la Edad Media. Debido a unos factores concretos, la producción

historiográfica en estos últimos años ha sido abundante y se ha distribuido en torno a las dos líneas tradicionales de análisis: la devocional y la laboral. Sin embargo, faltan estudios que conciban las cofradías medievales como un verdadero fenómeno social y existen aún líneas inexploradas para el caso de estas asociaciones en la Corona de Castilla que deberían marcar la dirección de los trabajos a partir de ahora. En la última parte se recopila una selección

bibliográfica de los estudios publicados sobre el tema entre 1996 y 2011.
\end{abstract}

\begin{abstract}
An examination of scholarship on collective action and confraternities in medieval Castile suggests a significant renovating change in the last fifteen years after decades without much innovation. Due to various factors, scholarship in the last few years has been abundant and can be divided into two main lines of research: the devotional confraternity and the guild. However, there are few studies concerning medieval confraternities as an authentic social phenomenon in the Crown of Castile and many unexplored issues in this area that require further research. In the last section, a bibliographical selection of the studies published on this subject from

1996 to 2011 has been compiled.
\end{abstract}

* Fecha de recepción del artículo: 2012-1-14. Fecha de aceptación del artículo: 2012-2-10.

** Universidad Carlos III de Madrid. C.e.: a.martinviverostajuelo@yahoo.es 


\section{PALABRAS CLAVE}

Asociacionismo, cofradías, Corona de Castilla, Edad Media, historiografía, bibliografía.

\section{KEY WORDS}

Collective action, Confraternities, Crown of Castile, Middle Ages, Scholarship, Bibliography.

\section{INTRODUCCIÓN}

La XXV Semana de Estudios Medievales de Estella, celebrada en 1998, generó un importante número de trabajos que dibujaban el panorama de las condiciones que hicieron posible un exponencial crecimiento de los estudios de Historia Medieval desde el año 1968. José Ángel García de Cortázar y Julio Valdeón ${ }^{1}$ apuntaban en el análisis de aquellas jornadas las causas políticas, administrativas, académicas y tecnológicas que habían hecho posible que en los últimos treinta años el volumen y, por consiguiente, el auge de los estudios sobre la Edad Media en España hubieran experimentado un impulso sin parangón.

Ante la imposibilidad de exponer el desarrollo de todas las áreas de estudio de la Edad Media centraremos el análisis en un aspecto concreto. El objetivo de este artículo es hacer una revisión de la historiografía referida al tema del asociacionismo y las cofradías en la Castilla medieval en los últimos quince años y apuntar de modo exhaustivo la bibliografía que se ha generado al respecto desde el año 1996 hasta la actualidad. Resulta de gran interés analizar la progresión de los trabajos relacionados con este tema específico, con el objetivo de seguir investigando y poner de manifiesto las razones por las cuales dichos estudios se han desarrollado con unas características muy particulares.

El marcado localismo y el carácter referencial dentro de marcos más generales han obligado al investigador a manejar gran cantidad de documentos primarios y bibliografía de naturaleza muy dispar. Por esta razón, intentando remontarnos a una de las líneas más centradas en el tema, he seguido a la investigadora Gregoria Cavero y he partido del año en el que publica una tipología de cofradías basada en las asociaciones cofrades de Astorga, pero que presuntamente puede utilizarse para todas las cofradías ${ }^{2}$. A partir de entonces se observa cómo el nivel de producción de los últimos quince años se sitúa en cerca de un $50 \%$ de los estudios publicados sobre el tema que nos ocupa, casi el mismo porcentaje que los publi-

1 Cf. GARCÍA DE CORTÁZAR Y RUÍZ DE AGUIRRE, José Ángel, «Glosa de un balance sobre la historiografía medieval española de los últimos treinta años (I)» en XXV SEMANA DE ESTUDIOS MEDIEVALES, La Historia Medieval de España. Un balance historiográfico (1968-1998), Pamplona, Gobierno de Navarra, 1999, pp. 807-824. VALDEÓN BARUQUE, Julio, «Glosa de un balance sobre la historiografía medieval española de los últimos treinta años (II)», en Idem., pp. 825-842.

2 CAVERO DOMÍNGUEZ, Gregoria, "Las cofradías de Astorga a finales del siglo XV: tipología de su documentación», en Memoria Ecclesiae, 1996, ํo 8, págs. 401-405. 
cados entre 1968 y 1996, frente a al escaso $10 \%$ que suponen las publicaciones desde el siglo XIX hasta finales de los años sesenta del pasado siglo. Es posible que esta distribución en porcentajes de la producción historiográfica pueda tomarse como un dato anecdótico, pero da razón de que estamos ante uno de los temas que han cobrado mayor auge en los últimos quince años que en las tres décadas de florecimiento de los estudios medievales que se planteaban en el análisis de García de Cortázar y Valdeón.

Tres son las preguntas que vertebrarán este artículo. En primer lugar, nos cuestionaremos si el crecimiento experimentado en los estudios de Edad Media entre 1969 y 1998 se produjo también en el caso del asociacionismo y las cofradías en los territorios de la Corona de Castilla. En segundo lugar, cómo ha sido su desarrollo desde 1996, y cómo es en la actualidad el ritmo de trabajo en esta área, si se ha mantenido o si, por el contrario, se ha ralentizado. Finalmente, nos preguntaremos por los aspectos que necesitan un trabajo más profundo o por los temas que requieren más atención para completar el panorama de los estudios sobre las cofradías castellanas en la Baja Edad Media.

Para dar respuesta a estas preguntas y ofrecer un análisis historiográfico completo del tema del asociacionismo y las cofradías medievales en Castilla en los últimos quince años, analizaremos en la primera parte cuál fue el desarrollo que este tema experimentó en los treinta años de renacimiento e impulso de los estudios medievales en el siglo pasado a los que hacían referencia los autores citados. El análisis de la producción historiográfica de esas décadas permitirá contextualizar el auge que los estudios sobre cofradías tuvieron posteriormente. En la segunda parte se plantearán cuáles han sido las principales líneas de estudio desarrolladas en los últimos quince años, que no han hecho sino reforzar las líneas tradicionales de trabajo y devoción. Esta reflexión nos situará ante la necesidad de concretar en la tercera parte si han existido en este tiempo publicaciones que puedan ser consideradas hitos historiográficos y cuáles han sido los autores y autoras que en estos años han participado en el crecimiento de los estudios, desde qué punto de vista han desarrollado sus investigaciones y cómo han orientado sus trayectorias el tema que nos ocupa hacia el punto en el que nos encontramos actualmente.

Finalmente, plantearemos en la conclusión cuáles han sido y siguen siendo las luces y las sombras que han caracterizado la evolución de estos estudios. Esbozaremos además una reflexión sobre qué factores se pueden considerar determinantes para hablar de auge de esta área concreta de la Historia Medieval, factores generales y particulares que han hecho posible una producción historiográfica tan notable $\mathrm{y}$, por consiguiente, un avance investigador más que considerable desarrollado en poco tiempo. De igual manera, determinaremos el punto de la investigación en el que nos encontramos y la opinión sobre la dirección hacia la que deberían orientarse a partir de ahora, considerando las carencias que aún no han sido resueltas. 
El quinto epígrafe, planteado a manera de apéndice, contiene una selección bibliográfica de los estudios publicados entre 1996 y 2011 que resultan provechosos para el investigador en el tema del asociacionismo medieval y las cofradías en Castilla. Se trata de una bibliografía que puede resultar algo dispersa a simple vista y en algunas referencias, pues existen trabajos citados sobre cofradías de la Corona de Aragón o sobre otros temas que se ajustan a otras disciplinas académicas. No obstante, todos los trabajos a los que responden las referencias bibliográficas contribuyen a la comprensión de las cofradías de Castilla como fenómeno medieval.

\section{TREINTA AÑOS DE IMPULSO. EL DESARROLLO DEL TEMA EN LOS AÑOS DE LA RENOVACIÓN DE LOS ESTUDIOS SOBRE LA EDAD MEDIA}

José Sánchez Herrero señalaba en 1974 que el estudio de las cofradías y de los hospitales era uno de los capítulos olvidados en la renovación de los estudios medievales, explicando tal situación por la escasez de fuentes conocidas hasta el momento ${ }^{3}$. Sin embargo, en las dos décadas siguientes los trabajos sobre cofradías también fueron objeto de atención por parte de los investigadores. En 1971 veía la luz un importante artículo de Marie Claude Gerbert sobre las cofradías religiosas de Cáceres en el último tercio del siglo XV y el primero del XVI, completado ocho años después con otro artículo sobre la piedad popular en Extremadura $^{4}$, que se sitúan en una línea de análisis de religiosidad de la que formaron parte otros trabajos sobre ciudades como Toledo, Jaén, Sevilla, Burgos, Astorga o Logroño. De igual manera renacieron con fuerza los estudios sobre gremios y oficios, dentro de los cuales las cofradías ocupaban un papel más que significativo. Destacan en este sentido las publicaciones de Juan Garmendia Larrañaga o de Antonio Collantes de Terán, sobre los gremios del País Vasco y de Sevilla, respectivamente ${ }^{5}$. Es también significativa la importancia que tuvieron en esos años como objeto de estudio las asociaciones laborales de ciudades como Segovia, Zamora o las cofradías de pescadores de villas vascas como Bermeo.

Se puede afirmar que la renovación y el impulso al que se hacía referencia para los estudios sobre la Edad Media a partir de finales de los años sesenta tam-

${ }^{3}$ Cf. SÁNCHEZ HERRERO, José, «Cofradías, hospitales y beneficencia en algunas diócesis del Valle del Duero, siglos XIV y XV», en Hispania, CSIC, Madrid, 1974, № 34, pág. 5.

4 Cf. GERBERT, Marie Claude. «Les confréries religieuses à Cáceres de 1467 a 1523», en Mélanges de la Casa de Velázquez, Casa de Velázquez, Madrid, 1971, oํ 7, pp. 75-114; GARCíA LOBO, Vicente y José Manuel, «La piedad popular en Extremadura al final de la Edad Media», en Hispania Sacra, CSIC, 1979, vol. 31, pp. 89-151.

5 Cf. GARMENDIA LARRAÑAGA, Juan, Gremios, oficios y cofradías en el País Vasco, Caja de Ahorros Provincial de Guipúzcoa, 1979; COLLANTES DE TERÁN SÁNCHEZ, Antonio, «La formación de los gremios sevillanos. A propósito de unos documentos sobre los tejedores», en En la España Medieval, Universidad Complutense de Madrid, 1980, no 1, pp. 89-104. 
bién tuvieron su reflejo en el tema concreto de las cofradías medievales de CastiIla, con las limitaciones impuestas por la naturaleza del material de estudio. Los factores de diversa naturaleza que García de Cortázar y Valdeón señalaban como determinantes para tal auge influyeron de manera directa sobre las condiciones que hicieron posible dicho desarrollo. Pero al lado de esas causas políticas, académicas, tecnológicas y administrativas, los estudios sobre cofradías se vieron alentados por otras condiciones específicas que determinaron la base a partir de la cual pudieron proliferar gran número de estudios, la gran mayoría de ellos a partir de los años noventa.

En los años setenta renacía en España con gran fuerza la Semana Santa como manifestación religioso-cultural en la que las cofradías penitenciales ocupaban un lugar preferente, por lo que muchos estudios se dirigieron de acuerdo al interés general dominante de análisis de la cofradía penitencial. Eran décadas marcadas por la llegada de nuevos tiempos, de cambios religiosos y políticos: la herencia de un Concilio en la Iglesia que incitaba al laicado a participar de manera más activa en las manifestaciones de su fe, la apertura al mundo a través del turismo ofreciendo estampas costumbristas como la vida cofrade o las procesiones de penitencia, que se tradujo en una verdadera carrera por conseguir la declaración de Interés Turístico para la Semana Santa de diferentes lugares y en la necesidad de crear un corpus histórico para fundamentar tales pretensiones al tiempo que pudiera contribuir a afianzar sólidamente esas tradiciones y a perpetuarlas como patrimonio de un pueblo.

En esta línea de trabajo sobre las cofradías penitenciales, los estudios no vuelven la vista, generalmente, más allá del siglo XVI o XVII, pues es cierto que fue la nueva espiritualidad definida por el Concilio de Trento, entre otros muchos factores, la que propició la generalización de este tipo de cofradías y de sus registros escritos, imprescindibles para su reconstrucción posterior. Una parte considerable de los estudios sobre las hermandades penitenciales han fijado su atención en facetas de proyección externa como las procesiones, las estaciones de penitencia, el ornato, los enseres o la imaginería, aspectos que tienen más cabida aplicados a cofradías que hunden sus raíces en la espiritualidad barroca que las que proceden del periodo medieval.

Sin embargo, era necesario mirar a la Edad Media para descubrir el origen religioso, cultural y mental que daba lugar a las manifestaciones colectivas de la penitencia y también para analizar el precedente inmediato de tales asociaciones en el auge de las cofradías de la Vera Cruz o de los disciplinantes, documentadas a finales del siglo XV y comienzos del XVI en España, aunque, como ocurre con similares movimientos en Europa, pueda presuponerse en algunos casos españoles una existencia previa a las fechas en las que se documentan.

El impulso que experimentaron estos estudios estuvo muy determinado por la celebración de numerosos congresos y la formación de algunos institutos que contribuyeron a su evolución. El Congreso Nacional de Cofradías de Semana 
Santa, cuya primera edición tuvo lugar en Zamora en 1987, o la XIX Semana de Estudios Medievales de Estella, dedicada en 1992 a Cofradías, Gremios y Solidaridades $^{6}$, son ejemplos de que el interés por la historia de las cofradías medievales iba aumentando. De igual manera es importante señalar la creación de algunos institutos de investigación que nacieron con el objetivo de sistematizar los estudios y las fuentes que tenían que ver con las cofradías, buena muestra de lo cual fue la creación en 1991 del Centro de Estudio e Investigación de la Religiosidad Andaluza (CEIRA), dirigido por José Sánchez Herrero, que se creó, según recoge su estatuto fundacional, con el deseo de recopilar fuentes relacionadas con la religiosidad, entre las que se cuentan todas aquellas que tenían que ver con las cofradías, para poder sistematizarlas en sus publicaciones.

En conclusión, el asociacionismo y las cofradías experimentaron en esos treinta años un crecimiento paralelo al de otras áreas temáticas de los estudios de Historia Medieval. Con toda seguridad no se desarrollaron al ritmo que lo hicieron otros temas, porque las características del objeto de estudio no lo permitieron. Pero esos treinta años, con todas las causas de naturaleza general y particular que hemos señalado anteriormente, contribuyeron, en primer lugar, a sentar las bases sobre las que se desarrollaría el despegue posterior de los estudios y, en segundo lugar, a reforzar las líneas argumentales en las que se han situado los trabajos en los últimos años.

\section{EL TRABAJO Y LA DEVOCIÓN. LAS PRINCIPALES LÍNEAS DE INVESTIGACIÓN Y SU DESARROLLO A PARTIR DE 1996}

Los estudios sobre las cofradías medievales se han agrupado tradicionalmente en torno a dos líneas principales de análisis, líneas que responden a las dos grandes categorías de cofradías medievales o a las dos grandes funciones que estas asociaciones desarrollaban. La primacía de la dedicación de las cofradías a aspectos laborales o devocionales determina las dos líneas a las que hacemos referencia. Los estudios, pues, se agrupan en torno a una línea o a otra según se decanten por hacer en su exposición especial hincapié en los elementos propios de la cofradía como corporación de oficio o en los aspectos que la perfilan como una agrupación o asociación devocional en sentido amplio, aunque en ninguno de los dos casos se suele obviar que existe el otro tipo de cofradía. En cualquiera de estas vertientes se incide sobre el carácter benéfico-asistencial de dichas asociaciones, variando, por supuesto, el destinatario y la intencionalidad de tal acción según el caso.

\footnotetext{
6 Las conclusiones resultantes de jornadas de este tipo aportan a los estudiosos de la cofradías medievales la visión caleidoscópica que requiere el análisis de dichas asociaciones como fenómeno, la posibilidad de concebirlas como un prisma con diferentes caras complementarias, analizables desde la óptica de la solidaridad religiosa, la solidaridad urbana, su instrumentalización al servicio del poder, su concepción por parte de los laicos, por parte de los clérigos, etc.
} 
Un ejemplo de los trabajos que priman el carácter gremial o de oficio sobre otros elementos es la citada obra de Juan Garmendia, donde se afirma que en la Edad Media gremio y cofradía eran sinónimos y que, de hecho, para expresar la misma realidad, no se solía utilizar la palabra gremio en beneficio del uso de la palabra cofradía. En la década de los noventa, Juan Carrasco, en su artículo «Mundo corporativo, poder real y sociedad urbana en el Reino de Navarra", definía las cofradías en el mismo sentido, como asociaciones espontáneas en las que cristaliza la manifestación ciudadana y/o urbana de confraternidad laica, a la que se unen una o varias profesiones - de hombres y de mujeres - bajo el signo y amparo de una Iglesia común y un culto religioso común?

Como podemos observar, en concepciones del término como las de Garmendia o Carrasco, toda la confraternidad, solidaridad e incluso el culto común, que se deriva de las creencias compartidas en el marco de una misma Iglesia como institución integradora, se supeditan a la promoción social de los miembros de un determinado oficio como fin último de la asociación y no a otros fines de carácter espiritual, que serían los propios de una asociación de fieles meramente devocional. Manuel Ladero Quesada, en su obra Las ciudades medievales en la Corona de Castilla en la Baja Edad Media (siglos XIII al XV), publicada en 1996 refuerza esta idea ${ }^{8}$.

José Damián González Arce ha sido uno de los autores que más ha contribuido al desarrollo de la línea que prima los aspectos socio-laborales sobre los asistenciales, analizando diferentes asociaciones de oficio de algunas ciudades castellanas, como veremos más adelante. Por otra parte, hemos de señalar que la mayor actividad investigadora desarrollada en los últimos quince años sobre las corporaciones de oficio ha tenido lugar en el País Vasco. La Sociedad de Estudios Vascos y otras instituciones vascas han apoyado esta iniciativa con sus publicaciones; las cofradías de navegantes, mareantes, pescadores y el resto de oficios asociados con las faenas propias de la pesca en la costa vasca, las cofradías de San Pedro de diferentes localidades, como las de San Sebastián, Bermeo o San Vicente de la Barquera, han sido el objeto principal de estos estudios, que han puesto de manifiesto las actuaciones sociales, urbanas e incluso de participación política de estas cofradías, cuyas fuentes han sido muy generosas en este caso. En otras áreas de la Corona de Castilla, con menor fortuna en lo que respecta al hallazgo de fuentes, los estudios realizados han primado los análisis de cofradías de oficio que tienen que ver con las diferentes fases de la industria textil, así

7 CARRASCO, Juan, «Mundo corporativo, poder real y sociedad urbana en el Reino de Navarra (siglos XIII-XV)», en VV.AA., Cofradías, Gremios y Solidaridades en la Europa Medieval, XIX Semana de Estudios Medievales de Estella, 20-24 de julio de 1992, Gobierno de Navarra, Pamplona, 1993, pág. 229.

8 Manuel Ladero plantea que «las cofradías, además de las funciones asistenciales, aseguran la defensa de los intereses comunes de sus miembros y regulan, mediante ordenanzas internas, la jerarquización del oficio distinguiendo claramente entre los artesanos con taller propio, los oficiales y los aprendices». Cf. LADERO QUESADA, Manuel, Las ciudades de la Corona de Castilla en la Baja Edad Media (siglos XIII al XV), Arco Libros, Madrid, 1996, pág. 23. 
como de la platería. En la zona vasca del Reino de Castilla también ha sido importante el análisis que se ha realizado sobre cofradías de la industria del metal (tenaceros, cuchilleros, etc.) ${ }^{9}$.

De la segunda línea de investigación, la que considera los aspectos devocionales sobre los propiamente gremiales, encontramos como ejemplo la definición que ofrece, haciéndose heredera de los estudios devocionales encabezados por José Sánchez Herrero, Silvia María Pérez en 2005 en su obra Los laicos en la Sevilla Bajomedieval. Sus cofradías y devociones. Esta autora concibe las cofradías como asociaciones encaminadas al desarrollo espiritual de los componentes y la realización de prácticas misericordiosas como el entierro y el sufragio por los difuntos o el ejercicio de la penitencia ${ }^{10}$, pero reconoce también que las cofradías pudieron ser una institución propia de quienes se dedicaban a actividades profesionales del sector artesanal en sentido amplio, aunque aquellas que nacieron vinculadas de forma exclusiva a una actividad profesional, sobre todo a finales del siglo XV, abrieron pronto sus puertas a personas que se dedicaban a otro oficio.

La mayoría de los estudios que encontramos dedicados a la espiritualidad, al análisis de las cofradías como asociaciones devocionales de fieles ${ }^{11}$, se centran en lugares concretos, tienen un carácter local, pues responden al hallazgo de documentación precisa en los archivos de origen. Hay que señalar que la escasa do-

9 En esta línea destacan los análisis de Rosa MARTÍN VAQUERO (1996), Ernesto LÓPEZ LOSA (1997), Miren Koro SANTACANA CAMPOS (1997), Jon Andoni FERNÁNDEZ DE LARREA ROJAS (2000), Álvaro ARAGÓN RUANO y Xabier ALBERDI LONBIDE (2000), Aingueru ASTUI ZARRAGA (2003), Asier ROMERO ANDONEGUI (2003), Pedro CARRO MARTÍNEZ y Noemí GARCíA PUENTE (2004), Juan Carlos LUZURIAGA (2005), María Rosa AYERBE IRÍBAR (2007) y Juan Antonio BARRIO BARRIO (2007), la mayoría de ellos dedicados al fenómeno de las cofradías de pescadores.

10 La autora define exactamente la cofradía como «una asociación de fieles cristianos, laicos (hombres y mujeres) y clérigos, o laicos solos y clérigos solos, que se han unido para fines cristianos diferentes, de donde se deduce la diversidad de las cofradías, de las que señalamos como más comunes: el culto en sus múltiples manifestaciones, las muchas y diversas obras benéfico-asistenciales, el entierro y el sufragio por los difuntos, y la penitencia de los cofrades, que se establecieron sin la aprobación de la autoridad eclesiástica (del siglo XVI en adelante) o con la necesaria y exigida aprobación de la autoridad real o de la Cámara de Castilla en la segunda mitad del siglo XVIII». Cf. PEREZ GONZÁLEZ, Silvia María, Los laicos en la Sevilla Bajomedieval. Sus cofradías y devociones, Universidad de Huelva, 2005, pág. 115.

11 Podemos citar en este sentido a autores como José Sánchez Herrero, que han tratado la espiritualidad en sentido amplio, o a otros que se han ocupado en concreto de los diferentes aspectos de las cofradías devocionales, hablamos de investigadores como George GROSS (1997), Jesús ARRAIZA FRAUCA (1998) y Miguel Fernando GÓMEZ VOZMEDIANO (1999), que han centrado gran parte de sus estudios en asociaciones generadas en torno a la devoción al Apóstol Santiago, abogado de los peregrinos y de numerosas cofradías de caballeros; Manuel FLORIANO BRAVO (2007), en cuanto a la devoción cofrade a la Vera Cruz; y otros autores ocupados de diversas cofradías de devoción como Hipólito BARRIGUÍN (2009) para el caso de Toledo, Francisco Javier DOMÍNGUEZ BURRIEZA (2004) para Valladolid, Maㅡ Cruz GARCÍA TORRALBO (1998), Manuel NIETO CUMPLIDO (2004), Enrique GÓMEZ MARTÍNEZ (2006), y José DOMÍNGUEZ CUBERO (2008), entre otros, para las cofradías rurales de Andalucía, Ernesto IGLESIAS ALMEIDA (1997), Mercedes VÁZQUEZ BERTOMEU (1999), Xosé Manuel PEREIRA FERNÁNDEZ (2002), Olga GALLEGO DOMÍNGUEZ y Pedro LÓPEZ GÓMEZ (2002) para Galicia o Jesús GONZÁLEZ CELADA (2000) para las cofradías asturianas. 
cumentación primaria que existe se encuentra muy dispersa por archivos municipales, diocesanos, histórico-provinciales y de las diputaciones de cada una de las ciudades castellanas. A la proliferación de estos estudios han contribuido agentes como las instituciones locales interesadas en su publicación, sirvan como ejemplo el Boletín de Estudios Jiennenses, la Revista de Estudios Extremeños o la Sociedad de Estudios Vascos; revistas especializadas como Memoria Ecclesiae o Hispania Sacra; y la celebración de congresos, materializados en la publicación de sus actas, que han potenciado los análisis de los aspectos devocionales y más puramente religiosos de las cofradías. Buena muestra de ello son los Congresos anuales de Cofradías de Semana Santa y otros como los celebrados en el Escorial, con sus publicaciones Religiosidad Popular en España (2007) y El Culto a los santos: Cofradías, devoción, fiestas y arte (2008).

En esta misma tendencia argumental se sitúan otra serie de estudios que contemplan el fenómeno cofrade desde su faceta de asociaciones caritativas, de asistencia evangélica, ejercida por el imperativo del deber cristiano de practicar las obras de misericordia como consejo expiatorio de los pecados y condición para asegurarse la salvación, nunca en este caso por razones de tipo laboral. Se trata de estudios que describen y valoran el ejercicio hospitalario de los fieles cofrades que desempeñaban labores de gestión y asistencia a los pobres en hospitales y a los peregrinos en el caso de cofradías o ciudades próximas a lugares de peregrinación como el Camino de Santiago ${ }^{12}$. También existen más líneas temáticas dentro de las cofradías devocionales, sobre todo dos, que estudian la nueva espiritualidad colectiva del Sacramento eucarístico y de la devoción a la Sangre derramada en las procesiones de disciplina de las cofradías de la Vera Cruz en las décadas inmediatamente anteriores y posteriores al tránsito del siglo XV y $\mathrm{XVI}{ }^{13}$.

No es frecuente encontrar obras que contemplen el fenómeno de una manera general, existen algunos artículos y monografías que hacen hincapié en este aspecto $^{14}$, la última, como veremos en el siguiente epígrafe, de González Arce en 2009, once años después de que Benítez Bolorinos publicara su obra Las co-

12 Como ejemplo se pueden consultar los trabajos sobre las obras de misericordia de Antonio FURIÓ DIEGO (2002) y de Pedro Pablo HERRERA MESA (2006), y más específicamente sobre la asistencia hospitalaria de las cofradías, los de Juan Manuel BELLO LEÓN y María Antonia CARMONA RUIZ (1998), César Alonso de PORRES FERNÁNDEZ (2002) o Montserrat PRADA VILLALOBOS (2002 y 2003).

${ }_{13}$ Sobre la devoción eucarística hemos de señalar las publicaciones de Rosario ANGUITA HERRADOR (1996), Gregorio SILANES SUSAETA (1998), Raquel TORRES JIMÉNEZ (2002) y Soledad GÓMEZ NAVARRO (2006). Otros autores han contribuido con sus trabajos al estudio de las cofradías de la Vera Cruz y la devoción a la sangre de Cristo, destacan sobre todo José SÁNCHEZ HERRERO (2003) y Fermín LABARGA GARCÍA (1998, 1999 y 2001), entre otros como Germán NAVARRO ESPINACH (2006), Antonio MARTÍN-VIVEROS TAJUELO (2010) o Juan José MOYA MARTíNEZ (2010).

14 Algunos autores y autoras han orientado sus estudios hacia una visión más general, tomando como referencia las cofradías de una determinada acotación geográfica, muestra de lo cual son los trabajos de Gregorio SILANES SUSAETA (1997), Juan CORDERO RIVERA (1998), Ana María SABE ANDREU (2000), Daniel BALOUP (2003) o Silvia María PÉREZ GONZÁLEZ (2005). 
fradías medievales en el Reino de Valencia, magnífico análisis que consigue establecer una visión general del fenómeno cofrade medieval en dicho reino ${ }^{15}$.

Aparte de los estudios específicos sobre cofradías, existe otro material no menos importante en el que, sin ser las asociaciones cofrades el objetivo central del análisis, se ofrecen noticias y material que propician en el investigador interesantes reflexiones sobre múltiples aspectos relacionados con ellas. Este tipo de material forma parte de las investigaciones de numerosas disciplinas. Pueden encontrarse, pues, referencias a las cofradías en estudios sobre ciudades, en publicaciones de antropología, de arte, de teología, de derecho, de política o de conflictividad social ${ }^{16}$.

\section{VARIAS OBRAS PODRÍAN CONSIDERARSE HITOS HISTORIOGRÁFICOS}

Desde la publicación en 1944 de la obra de Antonio Rumeu de Armas, Historia de la Previsión Social en España: Cofradías, Gremios, Hermandades y Montepíos, y treinta años después del artículo de José Sánchez Herrero, «Cofradías, hospitales y beneficencia en algunas diócesis del Valle del Duero, siglos XIV y XV» (1974) y de la obra Las diócesis del Reino de León (1978), en las que ambos autores hicieron sendos tratados en los que incluían sus propias propuestas tipológicas sobre las cofradías medievales, se puede afirmar que ningún investigador se había propuesto hasta finales de los años noventa proyectar una visión de conjunto sobre el fenómeno de las cofradías. Juan Garmendia Larrañaga, como hemos señalado, lo había intentado poco después para el País Vasco, pero la intencionalidad de su obra era muy diferente a la de los autores anteriores.

15 Aludimos a la obra de Manuel Benítez Bolorinos en este momento como elemento de comparación con la publicación de José Damián González Arce por pretender ambas un planteamiento general del estudio de las cofradías medievales, siendo conscientes de que la primera no se circunscribe a los territorios de la Corona de Castilla. Las cofradías religiosas en el Reino de Valencia (Universidad de Alicante, 1998) es una buena muestra de los frutos historiográficos que ha dado la abundancia de fuentes para otros territorios de la península como la Corona de Aragón.

${ }^{16}$ Como por ejemplo en el estudio general sobre las ciudades de la Corona de Castilla realizado por Manuel Fernando LADERO QUESADA en 1996 o más recientemente sobre la ciudad de Zamora, publicado en 2004; en cuanto a trabajos centrados en cuestiones de Antropología podríamos destacar los de Isidoro MORENO NAVARRO (1999), Juan Antonio RUBIO ARDANAZ (2002), Ana María MARTÍNEZ DE SÁNCHEZ (2003), Miguel Ángel LADERO QUESADA (2004); los artículos de Ana Isabel UGALDE GOSROSTIZA (1996), Manuel VALDÉS FERNÁNDEZ (1996), Juan PLAZAOLA ARTOLA (2002), Emilio Antonio RIQUELME GÓMEZ (2008) para cuestiones de Arte; los trabajos sobre espiritualidad y movimientos evangélicos de Juan LOPEZ MARTíN (1996), Daniel de PABLO MAROTO (2000), Raquel TORRES JIMÉNEZ (2003), Francisco Javier FERNÁNDEZ CONDE (2004), o la bibliografía sobre antropología de la Religión propuesta por José Ignacio HOMOBONO MARTíNEZ (2006); la obra de Alberto RIBELOT CORTES (2002) sobre Derecho; y, finalmente, tocante a cuestiones referidas a política y conflictividad social, los trabajos de Susana y Marta TRUCHUELO GARCÍA (1998), Roberto de LORENZO PÉREZ DE SAN ROMÁN (2000), César GONZÁLEZ MÍNGUEZ (2000, 2001 y 2009), Juan Ignacio RUIZ DE LA PEÑA SOLAR (2004), Máximo DIAGO HERNANDO (2007 y 2009) e Ignacio MEDEL MARCHENA (2004), con su interesante aportación bibliográfica. 
Fue a mediados de los años noventa y sobre todo en la primera década del siglo XXI cuando tres investigadores a los que podemos considerar actualmente como los representantes de tres líneas propias de investigación sobre el asociacionismo cofrade medieval comenzaron a desarrollar la labor de difusión de los resultados de sus indagaciones derivadas de la elaboración de sus tesis doctorales. La primera investigadora a la que hacemos referencia es Gregoria Cavero Domínguez, autora que ya a finales de los años setenta y ochenta había apuntado las líneas de su análisis con publicaciones sobre las fiestas en las cofradías de Astorga y la Hospitalidad con los peregrinos del Camino de Santiago en dicha ciudad de la ruta jacobea. Pero fue en 1992 cuando publicó su monografía específica sobre las cofradías de Astorga en la Edad Media, en la que, tomando como referencia el nutrido campo de ejemplos que ofrecía la ciudad y los lugares aledaños que formaban parte del Camino, la autora proponía una nueva tipología con pretensión de que en ella pudiera encajar cualquier cofradía medieval que se descubriera en el futuro. Esta obra fue completada en el artículo sobre el mismo tema editado en 1996 en la revista Memoria Ecclesiae, que ha publicado varios trabajos de la autora. Así pues, numerosos artículos de Cavero Domínguez han contribuido de manera muy importante al avance del conocimiento en el tema de las cofradías medievales, totalmente centrada en la línea de dichas asociaciones como congregaciones devocionales de fieles con un marcadísimo carácter asistencial y hospitalario ${ }^{17}$.

Dentro de esta misma línea de especial consideración de los aspectos devocionales y de promoción espiritual de los fieles se sitúan los trabajos de Raquel Torres Jiménez, de la Universidad de Castilla-La Mancha. Esta autora, que ya en su tesis estudió el tema de las cofradías, ha desarrollado su labor investigadora sobre las asociaciones religiosas en el Campo de Calatrava utilizando como fuentes principales los Archivos Parroquiales y los libros de los visitadores de la Orden de Calatrava. Ha tratado el tema en un campo extenso y desde el punto de vista de la religiosidad popular, lo que le ha permitido analizar la relación que los mismos fieles que se agrupaban en las cofradías tenían con respecto a aspectos esenciales de la vida religiosa y devocional como la Eucaristía, las procesiones, las fiestas religiosas, la hospitalidad, el pecado o la salvación. Su primer trabajo, Religiosidad popular en el Campo de Calatrava: cofradías y hospitales al final de la Edad Media,

17 CAVERO DOMíNGUEZ, Gregoria, «Las fiestas de las cofradías astorganas (siglos XIV- XVI)» (1978); Peregrinos e indigentes en el Bierzo medieval (siglos XI-XVI): hospitales en el camino de Santiago (1987); Las cofradías en Astorga durante la Edad Media (1992); «Fundaciones hospitalarias del clero secular en la diócesis de Astorga (siglos XII-XV)» (1992); «Las cofradías de Astorga a finales del siglo XV: tipología de su documentación» (1996); "Cofradías y beneficencia en la Edad Media: aproximación a sus fuentes en los Archivos de la Iglesia» (1997); «Las cofradías impulsoras de la piedad popular» (2002); «Hospitalidad, vida monástica y santuarios en los caminos medievales de peregrinación» (2006); «La instrumentalización de la ayuda isidoriana en la Reconquista: la Cofradía del Pendón de Baeza en San Isidoro de León»(2006). 
publicado en 1989, ya apuntaba la dirección hacia la que esta autora iba a dirigir a lo largo de su carrera la mayor parte de sus investigaciones ${ }^{18}$.

En lo referente a la concepción esencial de las cofradías como asociaciones de oficio con intereses particulares en la gestión y defensa de todos los aspectos derivados de la actividad laboral encontramos los trabajos de Ernesto García Fernández ${ }^{19}$. Pero sobre todo hemos de destacar la prolífera obra de José Damián González Arce, en particular su libro Gremios y Cofradías en los siglos medievales de León y Castilla. Siglos XIV y XV. Se trata de una obra clave en cuanto a la interpretación global de la relación de los aspectos devocionales y propiamente gremiales de las cofradías en un campo tan extenso como son los Reinos de León y de Castilla ${ }^{20}$.

La obra de González Arce ha supuesto un gran avance, como las de las dos autoras anteriores, en el plano conceptual, pues ha introducido sin problema alguno la palabra gremio como sinónimo de cofradía en unos reinos medievales cuyas autoridades habían sido, según la historiografía anterior, contrarias a su fundación, y también en la medida en que se completa la visión global de la vida urbana y las actividades cotidianas y laborales de los hombres y mujeres en ciudades como Murcia, Sevilla, Toledo, Salamanca o Burgos ${ }^{21}$.

18 TORRES JIMÉNEZ, Raquel, Religiosidad popular en el Campo de Calatrava: cofradías y hospitales al final de la Edad Media (1989); «Devoción eucarística en el campo de Calatrava al final de la Edad Media: consagración y elevación» (2002); Formas de organización y práctica religiosa en Castilla la Nueva, siglos XIII-XVI, Tesis doctoral (2002); «Religiosidad laica en tierras calatravas: Cofradías de Valdepeñas al final de la Edad Media» (2002); "Pecado, confesión y sociedad bajo dominio calatravo al final del Medievo» (2003); "La influencia devocional de la Orden de Calatrava en la religiosidad de su señorío durante la Baja Edad Media» (2005); «Notas para una reflexión sobre el Cristocentrismo y la devoción medieval a la Pasión y para su estudio en el medio rural castellano» (2006).

${ }_{19}$ GARCÍA FERNÁNDEZ, Ernesto, «La Cofradía de San Juan de Arramele y las ordenanzas de Tolosa de 1501» (1994); «Las cofradías de oficios en el País Vasco durante la Edad Media (1530-1550)» (1997); «Las cofradías de oficios medievales del País Vasco (1350-1550)» (1999); «Las cofradías de mercaderes. mareantes y pescadores vascas en la Edad Media» (2005).

20 El autor ofrece también una visión general del fenómeno para Murcia en la obra del año 2000, Gremios, producción artesanal y mercado: Murcia, siglos XIV y XV.

21 GONZÁLEZ ARCE, José Damián, «El artesanado del Reino de Murcia en tiempos de la conquista (siglo XIII)» (1997); «Producción artesanal y fiscalidad comercial. Murcia ss. XIV-XV» (1999); Gremios, producción artesanal y mercado: Murcia, siglos XIV y XV (2000); «El gremio de carniceros de Sevilla y la fiscalidad sobre la venta de la carne (siglos XIII-XV)» (2006); «De la corporación al gremio. La cofradía de sastres, jubeteros y tundidores burgaleses en 1485» (2007); «Los cambistas compostelanos, un gremio de banqueros pioneros en la Castilla medieval (siglos XII-XV)» (2007); «Asociacionismo, gremios y restricciones corporativas en la España medieval (siglos XIII-XV)» (2008); «La cofradía medieval como precedente del gremio. Los mercaderes de Toledo durante el reinado de los Reyes Católicos» (2008); «Las cofradías del mar en la Corona de Aragón (siglos XIII-XV)» (2008); «La organización de la producción textil y las corporaciones gremiales en las ordenanzas generales de paños castellanas (14941511)» (2008); Gremios y Cofradías en los siglos medievales de León y Castilla. Siglos XIV y XV (2009); «La ventaja de llegar primero: estrategias en la pugna por la supremacía mercantil durante los inicios de los consulados de Burgos y Bilbao (1450-1515)» (2009); «La universidad de mercaderes de Burgos y el consultado castellano en Brujas durante el siglo XV» (2010); «Los gremios contra la construcción del libre mercado: la industria textil de Segovia a finales del siglo XV y comienzos del XVI» (2010). 


\section{LUCES Y SOMBRAS. HACIA UNA NUEVA VISIÓN DE LAS COFRADÍAS COMO FENÓMENO SOCIAL}

La XXV Semana de Estudios Medievales de Estella marcó, en efecto, un punto de inflexión en los estudios de historiografía en tanto que sirvió, además de para reivindicar el valor de la labor historiográfica dentro del quehacer de los historiadores, para sacar a la luz interesantes reflexiones sobre lo acontecido en este ámbito desde 1968 hasta 1998, determinando las causas que motivaron el crecimiento y desarrollo de los estudios históricos, concretamente referidos a la Edad Media. Comenzábamos este estudio preguntándonos qué había ocurrido a partir de entonces y cuál era la situación en la actualidad. Hemos observado que temáticamente los trabajos siguen distribuyéndose de acuerdo con la tradicional división de analizar las cofradías medievales de las ópticas del asociacionismo devoto-asistencial o del asociacionismo laboral o de oficio. De igual manera, los trabajos siguen siendo bastante parciales, en el sentido de que la gran mayoría se centra en el estudio de una cofradía concreta dentro de un ámbito geográfico muy delimitado (una ciudad o una comarca), debido, como ya se ha dicho, a la dispersión de las fuentes que, por otra parte, se muestran poco generosas con el investigador.

Los últimos quince años han supuesto un gran avance para el estudio de las cofradías y el asociacionismo. Podemos afirmar que gran parte de esta situación se debe a que las causas que motivaron el desarrollo de otras áreas temáticas treinta años antes han hecho más intensa su labor, incidiendo directamente sobre un tema como el que nos ocupa. Por ejemplo, la eclosión de los estudios sobre religiosidad medieval en el marco de la renovación de la Historia de la Iglesia supuso un gran impulso para el interés por las cofradías medievales, también en Castilla. Pero los trabajos sobre cofradías siguen teniendo hoy el mismo carácter que han tenido durante el siglo $\mathrm{XX}$, continúan siendo por lo general bastante fragmentarios y dispersos, quedando en multitud de ocasiones insertos en análisis no dedicados específicamente a las cofradías, lo que se debe a la naturaleza misma de las fuentes.

La reorganización y digitalización en estos últimos años de muchos archivos, tanto nacionales como locales, ha facilitado en gran medida el acceso del investigador a la documentación requerida, ampliando las posibilidades de recuperación de la misma. Así, la posibilidad de acceder a gran cantidad de esta información a través de la red y a los resultados que van generando las investigaciones de los historiadores a este respecto, ha abierto nuevos foros de conocimiento actualizado que contribuye cada vez más a la ruptura de esa fragmentariedad de estudios y a potenciar nuevos análisis de carácter global, orientándose hacia la concepción de las cofradías como un fenómeno social en el que convergen infinidad de aspectos explicativos de la vida de los hombres y mujeres de la Edad Media.

No menos importantes han sido las ediciones de fuentes y las catalogaciones de archivos, así como aquellos estudios que recogen información sobre las co- 
fradías a pesar de no ser ese su objetivo principal. Hemos de señalar la importancia de los trabajos de algunos autores que se han encargado de publicaciones de fuentes documentales. Luis Calvo, José Ángel Lema Pueyo y Montserrat Fernández, entre otros, han editado la documentación de archivos, en gran parte vascos, como el municipal de Deba, el catedralicio de Astorga, el municipal de Laredo, el parroquial de Villalpando (Zamora) o los municipales de Mutriku y Bergara, que siguen la iniciativa de publicación de fuentes que la Editorial de la Universidad de Salamanca iniciara años antes con las ediciones de las colecciones documentales de archivos como el de la Catedral de Ávila (1973) o el municipal de Alba de Tormes $(1982)^{22}$. Una publicación sumamente relevante para el estudio de las cofradías vio la luz en 2002, CXIX Reglas de Hermandades y Cofradías andaluzas: siglos XIV, $X V$ y XVI, editado por la Universidad de Huelva en formato tradicional y en CDRom, bajo la coordinación de José Sánchez Herrero y Silvia María Pérez Gonzá$l e z^{23}$.

Otros autores han propuesto en sus publicaciones apuntes sobre la existencia y la calidad de la documentación de determinados archivos, aunque no han facilitado sus transcripciones. Aún así, también estos trabajos de catalogación o de sistematización de los documentos y fuentes existentes son de gran utilidad, sobre todo para acceder a la documentación de interés conociendo su localización o descartar su existencia en determinados archivos. Sirvan como ejemplo los trabajos de Roldán Jimeno Aranguren o de Christian Madsen y Manuela Infante sobre el Archivo Histórico de Ciudad Real, o los trabajos de la antes citada Raquel Torres sobre las fuentes de sus investigaciones en el Campo de Calatrava ${ }^{24}$.

Todo ello ha conformado un contexto que ha hecho posible el auge al que venimos haciendo referencia desde el comienzo del artículo. Sin embargo, considero que deberían abrirse nuevas líneas de análisis que profundizaran, por ejemplo, en la relación de las cofradías medievales con las autoridades eclesiásticas, aspecto interesante que no ha sido tratado con el mismo interés con el que se han analizado las relaciones de los cofrades con las autoridades civiles. Se han de seguir potenciando los estudios que den unidad general al fenómeno cofrade en la Edad Media, estudios que han sido más fructíferos para lugares como Aragón, donde la documentación es mucho más abundante, está más organizada y, sobre todo, centralizada. Con toda seguridad las características

22 Por su aportación al estudio de la cofradías son muy destacables, entre otras, las colecciones documentales de los archivos municipales de Deba [Elena BARRENA OSORO y Victoriano José HERRERO LICEAGA (2005)], Mutriku [Montserrat FERNÁNDEZ (2007)] y Vergara [José Ángel LEMA PUEYO (2007)]; de archivos catedralicios como el de Astorga [Gregoria CAVERO DOMÍNGUEZ y María Encarnación MARTÍN LÓPEZ (1999)]; y de otros archivos como los de las villas de Villalpando [Luis CALVO LOZANO (2003)] o Laredo [Virginia CUÑAT CISCAR (1998)].

${ }_{23}$ SÁNCHEZ HERRERO, José (ed.) y PÉREZ GONZÁLEZ, Silvia María (coord.), CXIX Reglas de Hermandades y Cofradías andaluzas: siglos XIV, XV y XVI, Universidad de Huelva, Huelva, 2002.

${ }^{24}$ Es muy importante destacar a este respecto las publicaciones de Roldán JIMENO ARANGUREN, (1999), Christian MADSEN VISEDO y Manuela INFANTE PRIETO (2002), Raquel TORRES JIMÉNEZ (2009). 
particulares de cada asociación cofrade en Aragón, en el resto de Europa o en Castilla responden a las mismas necesidades antropológicas, sociales y espirituales de los fieles. Además, contamos para Castilla, como hemos expuesto, con una ventaja derivada de la dispersión de fuentes, ya que si bien los archivos no se han mostrado generosos, sí lo ha hecho la historiografía, que sirve para sentar una sólida base teórica sobre la que levantar una argumentación general y caleidoscópica del fenómeno a partir de los documentos inéditos que se vayan localizando en los archivos.

\section{BIBLIOGRAFÍA SOBRE COFRADÍAS CASTELLANAS BAJOMEDIEVALES. 1996-2010}

ANGUITA HERRADOR, Rosario, "Asociaciones Sacramentales en la provincia de Jaén». La Cofradía del Santísimo Sacramento», en Boletín del Instituto de Estudios Giennenses, Jaén, 1996, no 160, pp. 51-61.

ARAGÓN RUANO, Álvaro y ALBERDI LONBIDE, Xabier, «El proceso de institucionalización de las cofradías guipuzcoanas durante la Edad Moderna: cofradías de mareantes y de podavines", en Vasconia. Cuadernos de Historia-Geografía, Sociedad de Estudios Vascos, San Sebastián, 2000, no 30, pp. 205-222.

ARIZAGA BOLUMBURU, Beatriz y MARTÍNEZ MARTíNEZ, Sergio, Atlas de villas medievales de Vasconia, Bizcaia, Sociedad de Estudios Vascos, San Sebastián, 2006.

ARRAIZA FRAUCA, Jesús,

- Cofradías de Santiago en Navarra, Gobierno de Navarra, Pamplona, 1998.

- "Cofradía de Santiago en la Pamplona de los siglos XIII y XIV», en Príncipe de Viana, Gobierno de Navarra, Pamplona, 2001, no 222, pp. 77-86.

ASTUI ZARRAGA, Aingeru, "Cambios en las técnicas de pesca: Ecología vs. Economía», en Zainak. Cuadernos de Antropología-Etnografía, Sociedad de Estudios Vascos, San Sebastián, 2003, ํㅜ 25, pp. 389-409.

AYERBE IRÍBAR, María Rosa, "Ordenanzas de la cofradía de mareantes de San Pedro, en San Sebastián (1489)», en Boletín de estudios históricos sobre San Sebastián, 2007, no 41, pp. 417-437.

BALOUP, Daniel et al. L enseignement religieux dans la Couronne de Castille. Incidences spirituelles et sociales (XIIlème- XVème siècle), Casa de Velázquez, Madrid, 2003.

BALSA DE PINHO, Joana, «Los santos y las cofradías de la Misericordia en Portugal», en VV.AA., El culto a los santos: Cofradías, devoción, fiestas y arte, Ediciones Escurialenses, 2008, pp. 781-790.

BARRENA OSORO, Elena y HERRERO LICEAGA, Victoriano José, Archivo Municipal de Deba I (1185-1520), Sociedad de Estudios Vascos, San Sebastián, 2005.

BARRIGUÍN, Hipólito, «La Cofradía de la Inmaculada de Toledo y el Cardenal Cisneros: un modelo de asociación mariana y benéfica», en Archivo Ibero-Americano, Franciscanos Españoles, 2009, no 264, año oㅡ 69, pp. 585-624.

BARRIO BARRIO, Juan Antonio, "Las reformas de la industria textil pañera en la ciudad de Orihuela en la primera mitad del siglo XV», en Miscelánea Medieval Murciana, Universidad de Murcia, 2007, vol. 31, pp. 39-68.

BELLO LEÓN, Juan Manuel y CARMONA RUIZ, María Antonia, "Ordenanzas del Hospital Real de Sevilla (años 1500-1526)», en Miscelánea Medieval Murciana, Universidad de Murcia, 1998, pp. 9-42. 
BENÍTEZ BOLORINOS, Manuel, Las cofradías religiosas en el Reino de Valencia (1329-1458), Universidad de Alicante, 1998.

CALVO LOZANO, Luis et al., Parroquias, Archivos y Cofradías de Villalpando, Centro de Estudios Benaventanos «Ledo del Pozo», Benavente, 2003.

CARRO MARTÍNEZ, Pedro y GARCÍA PUENTE, Noemí, «Aspectos de seguridad en la pesca de bajura», en Prevención, trabajo y salud: Revista del Instituto Nacional de Seguridad e Higiene en el Trabajo, Madrid, 2004, ํo 30.

CAVERO DOMÍNGUEZ, Gregoria, ÁLVAREZ, César y MARTíN FUERTES, José Antonio, Colección Documental del Archivo Diocesano de Astorga, Colección de Fuentes y Estudios de Historia Leonesa, León, 2001.

CAVERO DOMÍNGUEZ, Gregoria y MARTÍN LÓPEZ, María Encarnación, Colección documental de la Catedral de Astorga. I, (646-1126), Centro de Estudios e Investigación "San Isidoro», León, 1999.

CAVERO DOMÍNGUEZ, Gregoria,

- «Las cofradías de Astorga a finales del siglo XV: tipología de su documentación», en Memoria Ecclesiae, 1996, ํo 8, pp. 401-405.

- «Cofradías y beneficencia en la Edad Media: aproximación a sus fuentes en los Archivos de la Iglesia», en Memoria Ecclesiae, Asociación de Archivos de la Iglesia en España, 1997, no 11, pp. 455-471.

- «Las cofradías impulsoras de la piedad popular», en Memoria Ecclesiae, 2002, no 21, pp. 9-95.

- «Hospitalidad, vida monástica y santuarios en los caminos medievales de peregrinación», en Diversarum rerum: revista de los Archivos Catedralicio y Diocesano de Ourense, 2006, no 1, pp. 205-230.

- «La instrumentalización de la ayuda isidoriana en la Reconquista: la Cofradía del Pendón de Baeza en San Isidoro de León», en Aragón en la Edad Media, Universidad de Zaragoza, Zaragoza, 2006, no 19 (ejemplar dedicado como homenaje a la profesora María Isabel Falcón), pp. 113-124.

CEBALLOS-ESCALERA GILA, Alfonso de,

- «Breves notas sobre los orígenes y la evolución de la heráldica hispana», en Cuadernos de Historia-Geografía, San Sebastián, 2010, pp. 85-122.

- «El escudo de Guipuzkoa. Una aproximación a la Heráldica Institucional de los territorios de lengua vasca», en Cuadernos de Historia-Geografía, San Sebastián, 2010, pp. 41-84.

CORDERO RIVERA, Juan, «Asociacionismo popular: gremios, cofradías, hermandades y hospitales», en IGLESIA DUARTE, José Ignacio de la (coord.), La vida Cotidiana en la Edad Media. VIII Semana de Estudios Medievales de Nájera, Instituto de Estudios Riojanos, Logroño, 1998, pp. 387-400.

CUÑAT CISCAR, Virginia, Documentación Medieval de la Villa de Laredo (1200-1500), Fundación Marcelino Botín, Santander, 1998.

DIAGO HERNANDO, Máximo,

- «El factor religioso en el conflicto de las Comunidades de Castilla (1520-1521). El papel del clero", en Hispania Sacra, CSIC, Madrid, 2007, vol. 119, pp. 85-140.

- «La incidencia de los conflictos banderizos en la vida política de las ciudades castellanas a fines de la Edad Media: el caso de Cuenca», en Hispania. Revista Española de Historia, CSIC, Madrid, 2009, vol. 69, no 233, pp. 683-714.

DOMÍNGUEZ BURRIEZA, Francisco Javier, «Principio y fin de la sede de la cofradía de Nuestra Señora del Val y San Eloy en el casco urbano de Valladolid», en Boletín del Seminario de Estudios de Arte y Arqueología, Universidad de Valladolid, 2003-2004, tomo 69-70, pp. 341-358.

DOMÍNGUEZ CUBERO, José, «Estatutos de la Cofradía de la Virgen de la Cabeza de Lucena», en ELUCIDARIO, 2008, no 6, pp. 55-65. 
FERNÁNDEZ CONDE, Francisco Javier, «Movimientos de Pobreza Evangélica e Iglesia Oficial: Conflictividad Interreligiosa», en IGLESIA DUARTE, José Ignacio (coord.), Conflictos Sociales, Políticos e Intelectuales en la España de los Siglos XIV y XV, Instituto de Estudios Riojanos, Logroño, 2004, pp. 285-334.

FERNÁNDEZ DE LARREA ROJAS, Jon Andoni, «Notas para el estudio de las relaciones y conflictos laborales en el mundo artesanal en la Navarra bajomedieval (siglos XIV-XV)", en Vasconia. Cuadernos de Historia-Geografía, Sociedad de Estudios Vascos, San Sebastián, 2000, no 30, pp. 59-72.

FERNÁNDEZ, Montserrat, et al., Fuentes Medievales en el Archivo Municipal de Mutriku (12371520), Sociedad de Estudios Vascos, San Sebastián, 2007.

FLORIANO BRAVO, Manuel, «La espiritualidad de la cofradía de la Santa y Vera Cruz a través de sus estatutos», en Cauriensia: revista anual de Ciencias Eclesiásticas, Instituto Teológico «San Pedro de Alcántara», Universidad de Extremadura, Cáceres, 2007, № 2, pp. 511-518.

FURIÓ DIEGO, Antonio, «El nuevo auge de la esclavitud al final de la Edad Media», en CHUST CALERO, Manuel (coord.), De la cuestión señorial a la cuestión social: Homenaje al profesor Enric Sebastià, Universidad de Valencia, Valencia, 2002, pp. 23-38.

GALLEGO DOMínGUEZ, Olga y LÓPEZ GÓMEZ, Pedro, «La Cofradía de Santiago de los Caballeros de Ourense y sus banquetes festivos", en VV.AA., Iglesia y Religiosidad en España. Historia y Archivos, ANABAD CASTILLA-LA MANCHA, GUADALAJARA, 2002, vol. II, pp. 1455-1487.

GARCÍA FERNÁNDEZ, Ernesto,

- «Las cofradías de oficios en el País Vasco durante la Edad Media (1530-1550)», en Studia historica. Historia medieval, Universidad de Salamanca, 1997, no 15, pp. 11-40.

- «Las cofradías de oficios medievales del País Vasco (1350-1550)", en Historiar: Revista trimestral de historia, L avenç, 1999, no 1, pp. 76-90.

- «Las cofradías de mercaderes. mareantes y pescadores vascas en la Edad Media», en Ciudades y villas portuarias del Atlántico en la Edad Media: Nájera. Encuentros Internacionales del Medievo, Nájera, 27-30 de julio de 2004, Nájera, 2005, pp. 257-294.

GARCÍA TORRALBO, Ma Cruz, "Las cofradías religiosas de Baeza: precisiones históricas y artísticas», en Boletín del Instituto de Estudios Giennenses, Jaén, 1998, no 198, pp. 27-41.

GÓMEZ MARTÍNEZ, Enrique, «Los estatutos de 1505 de la Cofradía de la Virgen de la Cabeza de Andújar (Jaén)», en Boletín del Instituto de Estudios Giennenses, Jaén, 2006, no 194, pp. 111138.

GÓMEZ NAVARRO, Soledad, «La Eucaristía en el corazón del siglo XVI», en Hispania Sacra, CSIC, Madrid, 2006, vol. 118, pp. 489-515.

GÓMEZ VOZMEDIANO, Miguel Fernando,

- «Devociones religiosas colectivas y conversos en Almagro. La cofradía de Santa María de Mirabuenos (ss. XV-XVII)», en Hispania Sacra, CSIC, Madrid, 1998, no 101, pp. 65-100.

- «La Cofradía y Hermandad de Caballeros de Santiago en Puebla de Alcocer (siglos XIIIXVIII)», en Revista de estudios extremeños, Centro de Estudios Extremeños, Diputación de Badajoz, 1999, no 3, vol. 55, pp. 973-994.

GONZÁLEZ ARCE, José Damián,

- «El artesanado del Reino de Murcia en tiempos de la conquista (siglo XIII)», Murgetana, Real Academia Alfonso X el Sabio, Murcia, 1997, no 96, pp. 5-27.

- «Producción artesanal y fiscalidad comercial. Murcia ss. XIV-XV», en Murgetana, Real Academia Alfonso X el Sabio, Murcia, 1999, oㅜ 99, pp. 93-107.

- Gremios, producción artesanal y mercado: Murcia, siglos XIV y XV, Universidad de Murcia, 2000.

- «El gremio de carniceros de Sevilla y la fiscalidad sobre la venta de la carne (siglos XIII-XV)», en Historia, instituciones, documentos, Universidad de Sevilla, 2006, № 33, pp. 255-290. 
- «De la corporación al gremio. La cofradía de sastres, jubeteros y tundidores burgaleses en 1485», en Studia historica. Historia medieval, Universidad de Salamanca, 2007, no 25, pp. 191-219.

- «Los cambistas compostelanos, un gremio de banqueros pioneros en la Castilla medieval (siglos XII-XV)», en Medievalismo: Boletín de la Sociedad Española de Estudios Medievales, Madrid, 2007, no 17, pp. 85-120.

- «Asociacionismo, gremios y restricciones corporativas en la España medieval (siglos XIIIXV)", en Investigaciones de historia económica: revista de la Asociación Española de Historia Económica, Universidad de Salamanca, 2008, no 10, pp. 9-34.

- «La cofradía medieval como precedente del gremio. Los mercaderes de Toledo durante el reinado de los Reyes Católicos", en En la España Medieval, Universidad Complutense de Madrid, Madrid, 2008, vol. 31, pp. 177-216.

- «La organización de la producción textil y las corporaciones gremiales en las ordenanzas generales de paños castellanas (1494-1511)", en Anuario de estudios medievales, CSIC, Madrid, 2008, no 38, 2, pp. 707-759.

- «Las cofradías del mar en la Corona de Aragón (siglos XIII-XV)», en Espacio, tiempo y forma. Serie III, Historia medieval, UNED, 2008, oㅡ 21, pp. 285-310.

- «La ventaja de llegar primero: estrategias en la pugna por la supremacía mercantil durante los inicios de los consulados de Burgos y Bilbao (1450-1515)", en Miscelánea medieval murciana, Universidad de Murcia, 2009, vol. 33, pp. 77-97.

- Gremios y Cofradías en los siglos medievales de León y Castilla. Siglos XIV y XV, Región Editorial, Palencia, 2009.

- «La universidad de mercaderes de Burgos y el consultado castellano en Brujas durante el siglo XV», en En la España medieval, Universidad Complutense de Madrid, 2010, nº 33, pp. 161-202.

- «Los gremios contra la construcción del libre mercado: la industria textil de Segovia a finales del siglo XV y comienzos del XVI», en Revista de Historia industrial, Universitat de Barcelona, 2010, no 42, pp. 15-42.

GONZÁLEZ CELADA, Jesús, «Las Cofradías de San Emeterio y San Celedonio en Asturias» en Kalakorikos, Amigos de la Historia de Calahorra, Calahorra, 2000, no5, pp. 257-270.

GONZÁLEZ MíNGUEZ, César,

- «La señorialización de Álava: el ejemplo de Berantevilla», en Espacio, tiempo y forma. Serie III. Historia Medieval, UNED, Madrid, 2000, no 13, pp. 103-118.

- «La concesión del Fuero Real a Vitoria», en Historia, instituciones, documentos, Universidad de Sevilla, Sevilla, 2001, № 28, pp. 217-229.

— «Las luchas por el poder en la Corona de Castilla: nobleza vs. monarquía (1252-1369)», en Clío \& Crimen, Universidad del País Vasco, 2009, ํo 6, pp. 36-51.

GROSS, Georg, «La carta de la cofradía de Santiago: documento histórico lingüístico de mediados del siglo XII», en Boletín de la Real Academia de la Historia, 1997, tomo 194, cuaderno 1, pp. 71-82

HERRERA MESA, Pedro Pablo, «La práctica de las Obras de Misericordia en las cofradías cordobesas, siglos XIV-XVII», en La Iglesia española y las Instituciones de caridad, Ediciones Escurialenses, San Lorenzo del Escorial, 2006, pp. 92-122.

HINOJOSA MONTALVO, José Ramón, «San Blas, un santo universal para un cofradía medieval en Segorbe», en Boletín de la Sociedad Castellonense de Cultura, 2005, no 81, 1, pp. 325-351.

HOMOBONO MARTÍNEZ, José Ignacio, «Bibliografía sobre antropología de la Religión (II), en Zainak. Cuadernos de Antropología-Etnografía, Sociedad de Estudios Vascos, San Sebastián, 2006, no 28, pp. 543-579.

IGLESIAS ALMEIDA, Ernesto, «La cofradía do «Corpo Santo» de Pontevedra a través del tudense proceso de canonización de San Telmo», en El Museo de Pontevedra, 1997, no 51, pp. 647-658. 
JIMENO ARANGUREN, Roldán,

- «Fuentes para el estudio de la religiosidad», en Zainak. Cuadernos de Antropología-Etnografía, Sociedad de Estudios Vascos, San Sebastián, 1999, no 18, pp. 45-61.

- «San Gregorio Ostiense y su cofradía: revitalización festiva para la construcción comunitaria», en Fiestas, rituales e identidades, Zainak. Cuadernos de Antropología-Etnografía, Sociedad de Estudios Vascos, San Sebastián, 2004, no 26, pp. 189-208.

- El remedio sobrenatural contra las plagas agrícolas hispánicas: estudio institucional y social de la cofradía y santuario de San Gregorio Ostiense (siglos XIII-XIX), Cofradía de San Gregorio Ostiense, Sorlada (Navarra), 2005.

JIMENO JURíO, José María, «Eunate y su Cofradía. Ordenanzas Antiguas», en Príncipe de Viana, Gobierno de Navarra, Pamplona, 1997, № 210, pp. 87-118.

LABARGA GARCÍA, Fermín,

- «Las Cofradías de la Vera Cruz en La Rioja», en Berceo, Instituto de Estudios Riojanos, Logroño, 1998, no 134, pp. 105-142.

- «La devoción a las Cinco Llagas y a la Sangre de Cristo en las cofradías riojanas de la Vera Cruz", en Zainak. Cuadernos de Antropología-Etnografía, Sociedad de Estudios Vascos, San Sebastián, 1999, № 18, pp. 381-392.

- «Los pasos procesionales de las cofradías riojanas de la Vera Cruz», en Berceo, Instituto de Estudios Riojanos, Logroño, 2001, no 140, pp. 72-102.

- «El posicionamiento inmaculista de las cofradías españolas», en Anuario de Historia de la Iglesia, Universidad de Navarra, Pamplona, 2004, no 13, pp. 23-44.

LADERO QUESADA, Manuel Fernando,

- Las ciudades de la Corona de Castilla en la Baja Edad Media (siglos XIII al XV), Arco Libros, Madrid, 1996.

- «La ciudad de Zamora en la Edad Media. Reseña y Balance historiográfico», en Espacio, Tiempo y Forma, Serie III, Historia Medieval, UNED, Madrid, 2004, no 17, pp. 253-271.

LADERO QUESADA, Miguel Ángel. Las fiestas en la cultura medieval, Areté, Barcelona, 2004.

LEMA PUEYO, José Ángel,

- Colección Documental del Archivo Municipal de Bergara II. Fondo municipal: Subfondo Histórico (1355-1520), Fuentes Documentales Medievales del País Vasco, Sociedad de Estudios Vascos, San Sebastián, 2007.

- Colección Documental del Archivo Municipal de Bergara III. Fondo Iturbe-Eulate (1401-1520), Fuentes Documentales Medievales del País Vasco, Sociedad de Estudios Vascos, San Sebastián, 2007.

LÓPEZ LOSA, Ernesto, «La propiedad en el mar: acceso a los recursos y territorios de pesca. Las cofradías de mareantes de la costa vasca (XIV-finales del siglo XIX/principios del XX», en Zainak. Cuadernos de Antropología-Etnografía, Sociedad de Estudios Vascos, San Sebastián, 1997, no 15, pp. 199-217.

LÓPEZ MARTÍN, Juan, «Hermandades y cofradías en la vida de la Iglesia. Fundamentación teológica de la religiosidad popular», en Actas de las I Jornadas de Religiosidad Popular, Instituto de Estudios Almerienses, Almería, 1996, pp. 199-215.

LORENZO PÉREZ DE SAN ROMÁN, Roberto de, «Algunas consideraciones sobre los antecedentes de la Cofradía de Arriaga», en Sancho el Sabio, Revista de cultura e investigación vasca, Fundación Sancho el Sabio, Vitoria, 2000, no 13, pp. 153-184.

LUZURIAGA, Juan Carlos, Piedras Armeras de Agurain, Sociedad de Estudios Vascos, San Sebastián, 2005.

MADSEN VISEDO, Christian e INFANTE PRIETO, Manuela, «La documentación de Cofradías y Hospitales en el Archivo Histórico de Ciudad Real», en VV.AA., Iglesia y Religiosidad en España. Historia y Archivos, ANABAD CASTILLA-LA MANCHA, GUADALAJARA, 2002, vol. III, pp. 1359-1372. 
MARTÍN VAQUERO, Rosa, "Contribución al Estudio de la Platería Medieval Alavesa», en Cuadernos de Sección. Artes Plásticas y Monumentales. Revisión del Arte Medieval en Euskal Herria, San Sebastián, 1996, ํo 15, pp. 515-525.

MARTÍNEZ DE SÁNCHEZ, Ana María, «Función social y religiosa del espacio y el tiempo devocional», en Hispania Sacra, CSIC, Madrid, 2003, vol. 55, ㄲo 111, pp. 255-284.

MARTíNEZ SAN PEDRO, Mํㅡㄹ Desamparados, “Las Cofradías de Tabernas», en Actas de las I Jornadas de Religiosidad Popular, Instituto de Estudios Almerienses, Almería, 1996, pp. 243255.

MARTÍN-VIVEROS TAJUELO, Antonio, «La calle como escenario público de penitencia en la Baja Edad Media: la estación penitencial de las Cofradías de la Vera Cruz», en Revista de historiografía, 2010, no 12, pp. 84-92.

MEDEL MARCHENA, Ignacio, «Una aproximación bibliográfica», en IGLESIA DUARTE, José Ignacio (coord.), Conflictos Sociales, Políticos e Intelectuales en la España de los Siglos XIV y XV, Instituto de Estudios Riojanos, Logroño, 2004, pp. 531-585.

MORALES SOLCHAGA, Eduardo, "Cofradías bajo la advocación de San Lucas, protector de los pintores. En España. El caso de Navarra», en VV.AA., El culto a los santos: Cofradías, devoción, fiestas y arte, Ediciones Escurialenses, 2008, pp. 829-846.

MORENO NAVARRO, Isidoro, Las Hermandades andaluzas: una aproximación desde la Antropología, Universidad de Sevilla, Sevilla, 1999 ( $2^{\circ}$ ed.).

MOYA MARTÍNEZ, José Juan (coord.), Vid Salvífica: actas de las VI Jornadas Nacionales de Cofradías Medievales de la Sangre de Cristo, Antigua y Venerable Cofradía de la Sangre de Cristo y la Vera Cruz de Calasparra, Murcia, 2010.

NAVARRO ESPINACH, Germán, "Las cofradías de la Vera Cruz y de la Sangre de Cristo en la Corona de Aragón (siglos XIV-XVI)", en Anuario de Estudios Medievales, CSIC, Madrid, 2006, no 36 , pp. 583-611.

NIETO CUMPLIDO, Manuel, «Religiosidad popular andaluza: la regla medieval de la Cofradía de Animas de Castro del Río (Córdoba)» en Revista del Centro de Estudios Históricos de Granada y su Reino, 2004, no 16, pp. 257-282.

ORELLA UNZUÉ, José Luis, «Las Hermandades Vascas en el marco de la Santa Hermandad como instrumento de control de delitos e impartición de penas», en Clío \& Crimen: Revista del Centro de Historia del Crimen de Durango, 2006, № 3, pp. 68-133.

PABLO MAROTO, Daniel de, Espiritualidad de la baja Edad Media, Editorial de Espiritualidad, Madrid, 2000.

PASAMAR LÁZARO, José Enrique, «Inquisición en Aragón: la Cofradía de San Pedro Mártir de Verona», en Revista de Inquisición: (Intolerancia de Derechos Humanos), Universidad Complutense, Madrid, 1996, ํo 5, pp. 306-316.

PASCUAL Y HERMOSO DE MENDOZA, José Manuel, Una página de nuestra Historia. San Gregorio Ostiense y su cofradía, Cofradía de San Gregorio Ostiense, Sorlada, 1999.

PEÑAFIEL RAMÓN, Antonio, «Inquisición murciana y reorganización de la Cofradía de San Pedro Mártir de Verona», en Revista de Inquisición: (Intolerancia de Derechos Humanos), Universidad Complutense, Madrid, 2000, no 9, pp. 87-100.

PEREIRA FERNÁNDEZ, Xosé Manuel, «De «Cofradía do Corpo Santo» a Gremio de Mareantes», en El Museo de Pontevedra, 2002, no 56, pp. 157-168.

PÉREZ GONZÁLEZ, Silvia María, Los laicos en la Sevilla Bajomedieval. Sus cofradías y devociones, Universidad de Huelva, 2005.

PIÑOL I ALABART, Daniel, «Las notarías parroquiales tarraconenses en la Edad Media: fuentes para su estudio", en VV.AA., Iglesia y Religiosidad en España. Historia y Archivos, ANABAD CASTILLA-LA MANCHA, GUADALAJARA, 2002, vol. III, pp. 1347-1358.

PLAZAOLA ARTOLA, Juan, «El arte románico en Euskal Herria», en Revista Internacional de los Estudios Vascos, San Sebastián, 2002, pp. 93-181. 
POPOVIC, Alexandre y VEINSTEIN, Guilles (coords.), Las sendas de Allah. Las cofradías musulmanas desde sus orígenes hasta la actualidad, Bellaterra, Barcelona, 1997.

PORRES FERNÁNDEZ, César Alonso de, Cofradías y hospitales medievales burgaleses: "Santa Catalina y San Julián», Facultad de Teología del Norte de España, Burgos, 2002.

PRADA VILLALOBOS, Montserrat,

- «Las cofradías medievales y la asistencia hospitalaria: cuatro ejemplos en la ciudad de León: las cofradías de San Martín, los Calzadores, los Capellanes y Santiago", en Memoria Ecclesiae, Asociación de Archivos de la Iglesia en España, 2002, no 21, pp. 499-510.

- «Mayorga de Campos: un ejemplo de asociacionismo y ejercicio de la caridad en el mundo rural leonés durante la Edad Media», en Estudios Humanísticos. Historia, Universidad de León, León, 2003, no 2, pp. 27-36.

RIBELOT CORTÉS, Alberto, Manual de Derecho de las Cofradías de Sevilla, Grupo Nacional de Editores, Sevilla, 2002.

RIQUELME GÓMEZ, Emilio Antonio, "Santos intercesores del Purgatorio. Representaciones pictóricas en las cofradías de Ánimas murcianas, en VV.AA., El culto a los santos: Cofradías, devoción, fiestas y arte, Ediciones Escurialenses, 2008, pp. 491-506.

RODRÍGUEZ-PICAVEA MATILLA, Enrique, «El proceso de aristocratización de la Orden de Calatrava (siglos XIII-XV), en Hispania Sacra, CSIC, Madrid, 2007, vol. 120, pp. 493-535.

RODRÍGUEZ-SALA GOMEZGIL, María Luisa, «La Cofradía-Gremio durante la baja Edad Media y los siglos XVI y XVII, el caso de la Cofradía de los cirujanos, barberos, flebotomianos y médicos en España y la Nueva España", en Barataria: revista castellano-manchega de ciencias sociales, Asociación Castellano-manchega de Sociología, Toledo, 2009, no 10, pp. 149-163.

ROJO ALIQUE, Francisco Javier, «Reforma religiosa, política y sociedad civil en la Baja Edad Media: el ejemplo de San Francisco de Palencia en el Siglo XV», en Hispania Sacra, CSIC, Madrid, 2007, vol. 120, pp. 469-491.

ROMERO ANDONEGUI, Asier, «Una aproximación al estudio de los peces de mar en la documentación tardomedieval vizcaína», en Zainak. Cuadernos de Antropología-Etnografía, Sociedad de Estudios Vascos, San Sebastián, 2003, no 25, pp. 309-323.

RUBIO ARDANAZ, Juan Antonio, «La Antropología Marítima», en XV Congreso de Estudios Vascos, Sociedad de Estudios Vascos, San Sebastián, 2002, pp. 233-240.

RUIZ DE LA PEÑA SOLAR, Juan Ignacio, «Las ciudades de Señorío Eclesiástico y los conflictos por el control del Gobierno Local (1252-1350)», en IGLESIA DUARTE, José Ignacio (coord.), Conflictos Sociales, Políticos e Intelectuales en la España de los Siglos XIV y XV, Instituto de Estudios Riojanos, Logroño, 2004, pp. 113-145.

SABE ANDREU, Ana María, Las Cofradías de Ávila en la Edad Moderna, Institución Gran Duque de Alba, Diputación Provincial de Ávila, 2000.

SÁNCHEZ AMEIJEIRAS, Rocío, «La ritualización del camino de vuelta: nuevos hallazgos sobre el sepulcro de Santo Domingo de la Calzada», en GIL-DÍEZ USANDIZAGA, Ignacio (coord.), Arte medieval en la Rioja: Prerrománico y románico: VIII Jornadas de Arte y Patrimonio Regional, Instituto de Estudios Riojanos, Logroño, 2004, pp. 321-364.

SÁNCHEZ HERRERO, José (ed.) y PÉREZ GONZÁLEZ, Silvia María (coord.), CXIX Reglas de Hermandades y Cofradías andaluzas: siglos XIV, XV y XVI, Universidad de Huelva, Huelva, 2002.

SÁNCHEZ HERRERO, José,

- «Pasión y Sangre. En torno al origen de las Cofradías de Semana Santa Hispana», en BALOUP, Daniel et al., L enseignement religieux dans la Couronne de Castille. Incidences spirituelles et sociales (XIIlème- XVème siècle), Casa de Velázquez, Madrid, 2003.

- «Del Cristianismo culto a la Religiosidad Popular en la Edad Media», en Clío \& Crimen: Revista del Centro de Historia del Crimen de Durango, 2004, no 1, pp. 301-335.

- «Los orígenes de la Inquisición Medieval», en Clío \& Crimen: Revista del Centro de Historia del Crimen de Durango, 2005, ํㅡㄹ, pp. 17-52. 
SANTACANA CAMPOS, Miren Koro, «La caza de la ballena. Su influencia en los usos y costumbres desde la Edad Media», en Cuadernos de Antropología-Etnografía, Sociedad de Estudios Vascos, San Sebastián, 1997, no 15, pp. 251-262.

SENENT DÍEZ, Maㅡ Pía, «Más aportaciones para el estudio de la aljama hebrea de la villa de Ágreda», en Espacio, tiempo y forma. Serie III. Historia Medieval, UNED, Madrid, 2002, ㄲo 15, pp. 271-286.

SERRANO LARRAYOZ, "La cofradía del valle de Ulzama de Suso», en Príncipe de Viana, Gobierno de Navarra, Pamplona, 1998, no 214, pp. 413-432.

SERRANO MARTÍNEZ, Armando, "La cofradía de infanzones de San Jorge de Alcañiz (14701521)», en Aragón en la Edad Media, Universidad de Zaragoza, 2008, nº 20, pp. 757-777.

SILANES SUSAETA, Gregorio,

- «Las cofradías medievales en el reino de Navarra (siglos XI-XVI)», en Religiosidad popular en España: actas del Simposium: 1/4-IX-1997, Real Centro Universitario Escorial-María Cristina, San Lorenzo del Escorial, 1997, pp. 117-144.

- «La Cofradía del Santísimo Sacramento de Tudela», en Cuadernos de etnología y etnografía de Navarra, Gobierno de Navarra, Pamplona, 1998, no 71, pp. 53-58.

- «Contribución al estudio de la religiosidad pamplonesa en la baja edad media: las constituciones de la cofradía de Oculi Meì, en Navarra: memoria e imagen: Actas del VI Congreso de Historia de Navarra, Pamplona, 2006, vol. 1, pp. 227-240.

SUÁREZ GONZÁLEZ, Ana, «Datos sobre una cofradía medieval ¿inédita?», en Memoria Ecclesiae, Asociación de Archivos de la Iglesia en España, 2002, no 21, pp. 483-498.

TORRES JIMÉNEZ, Raquel,

- «Devoción eucarística en el campo de Calatrava al final de la Edad Media: consagración y elevación», en Memoria Ecclesiae, Asociación de Archivos de la Iglesia en España, 2002, oㅡ 20, pp. 293-328.

— «Religiosidad laica en tierras calatravas: Cofradías de Valdepeñas al final de la Edad Media», en VV.AA., Iglesia y Religiosidad en España. Historia y Archivos, ANABAD CASTILLA-LA MANCHA, GUADALAJARA, 2002, vol. II, pp. 653-677.

- Formas de organización y práctica religiosa en Castilla la Nueva, siglos XIII-XVI, Tesis doctoral dirigida por Miguel Ángel Ladero Quesada. Universidad Complutense de Madrid, 2002.

- «Pecado, confesión y sociedad bajo dominio calatravo al final del Medievo», en ADAO DA FONSECA, Luis (coord.), Os reinos ibéricos na Idade Media: livro de homenagem ao professor doutor Humberto Carlos Baquero Moreno, 2003, vol. 1, pp. 1267-1274.

— «La influencia devocional de la Orden de Calatrava en la religiosidad de su señorío durante la Baja Edad Media», en Revista de las Ordenes Militares, Real Consejo de las Órdenes Militares, 2005, no 3, pp. 37-74.

- «Notas para una reflexión sobre el Cristocentrismo y la devoción medieval a la Pasión y para su estudio en el medio rural castellano», en Hispania Sacra, CSIC, Madrid, 2006, nำ118, pp. 449-487.

— «Apéndice. Inventarios de libros de Iglesias Parroquiales. Campo de Calatrava, 1471-1537», en BOUCHERON, Patrick y RUIZ GÓMEZ, Francisco (coords.), Modelos culturales y normas sociales al final de la Edad Media, Casa de Velázquez - Universidad de Castilla-La Mancha, 2009, pp. 485-493.

- «Bibliotecas de parroquias rurales y religiosidad popular en Castilla al final de la Edad Media», en BOUCHERON, Patrick y RUIZ GÓMEZ, Francisco (coords.), Modelos culturales y normas sociales al final de la Edad Media, Casa de Velázquez - Universidad de Castilla-La Mancha, 2009, pp. 429-484.

TRUCHUELO GARCÍA, Susana y TRUCHUELO GARCÍA, Marta, «Reglamentación política de las villas guipuzcoanas en la Alta Edad Moderna: las ordenanzas concejiles de Rentería, Tolosa, 
Hondarribia y Orio", en Cuadernos de Historia-Geografía, Sociedad de Estudios Vascos, San Sebastián, 1998, no 25, pp. 387-353.

UGALDE GOSROSTIZA, Ana Isabel, «El programa iconográfico del coro de la Iglesia de Santa María de Vitoria», en Cuadernos de Sección. Artes Plásticas y Monumentales. Revisión del Arte Medieval en Euskal Herria, San Sebastián, 1996, no 15, pp. 423-436.

VALDÉS FERNÁNDEZ, Manuel, «Factores de unidad y diversidad en la arquitectura religiosa gótica vasca», en Cuadernos de Sección. Artes plásticas y monumentales, San Sebastián, 1996, no 15, pp. 103-123.

VÁZQUEZ BERTOMEU, Mercedes, «La cofradía de los clérigos de coro de Santiago y las ordenanzas de 1457 ", en Compostellanum, Centro de Estudios Jacobeos, Santiago de Compostela, 1999, vol. 44, pp. 445-493.

WILKINS, Nigel, «La fiesta de la Cofradía de arqueros, del Maestro de Frankfurt (1493), y la música en las cofradías», en Goldberg: Early music magazine = Revista de música antigua, Goldberg Ediciones, 2006, № 41, pp. 69-73. 
